with hormones in vivo, and to the examination of the responses of intact tissues, such as rat diaphragm, in vitro.

Prof. E. Fermi

Prof. Enrico Fermi, of the University of Chicago, is one of those rare physicists who is a leader both in the fields of abstract theory and of experimental technique. His many important contributions to modern physics include the statistical law applied to particles obeying the exclusion principle, the quantitative theory of $\beta$-transformations of nuclei, the discovery of artificial radioactivity induced by neutron bombardment and the improvement in efficiency of this process by the slowing down of neutrons. Fermi moved from Rome to the United States in 1939 and was associated with the American atomic energy project from its beginning. His imagination, ingenuity and drive was very largely responsible for the successful completion of the first chain-reacting pile at Chicago in 1942 . He is now working at the Institute of Nuclear Studies, Chicago. This list by no means exhausts the subjects to which Fermi has made contributions of decisive importance, nor does it include his indirect contribution to physics through the pupils to whom he has often succeeded in imparting some of that particular combination of sound intuition with simplicity of reasoning which is his strongest asset.

Prof. Carl Skottsberg

Prof. Carl Skotrsberg was born on December 1, 1880. His first botanical paper appeared in 1900, and since that year he has been actively engaged in researches on plant life. His publications number about 250 and cover a wide range of subjects, particularly in systematics and plant geography. Very early in his career, Prof. Skottsberg turned his attention to Antarctica and southern South America. Not only did he prepare many of the botanical accounts of the Swedish South Polar (or Antarctic) Expedition (1901-3) and the Swedish Expedition to Patagonia and Fuegia (1907-9), but also the latter was arranged by him. A summary of the botanical results, with bibliography, of these two expeditions was published in the Kew Bulletin, 268-79 (1919). Of wide general interest were his investigations on the flora and vegetation of Juan Fernandez, the Falklands, South Georgia and Graham Land. In a very readable book ("The Wilds of Patagonia", Edward Arnold, London, 1919) Skottsberg gives a general account of his travels on the mainland of Temperate South America. Later, he extended his researches to the Pacific islands by visits to Easter Island and Hawaii. In many papers he has dealt with the taxonomic and phytogeographical problems of their isolated flora. $\mathrm{He}$ has, however, always maintained his interest in the large area of his earlier field studies. His work throughout has mainly been concerned with the flowering plants and the brown seaweeds; but following on the results of his systematic reseßrches, he again and again links these with the wide problems of plant distribution. Prof. Skottsberg was elected a foreign member of the Linnean Society of London in 1943, and an honorary fellow of the Royal Society of Edinburgh in 1949. $\mathrm{He}$ is president designate of the Seventh International Botanical Congress to be held in Stockholm in July this year. He retired from the directorship of the Göteborg Botanic Garden on December 31, 1948.
UNDER the statute of the Royal Society which provides for the election of persons who either have rendered conspicuous service to the cause of science or are such that their election would be of signal benefit to the Society, Dr. G. M. Trevelyan, master of Trinity College, Cambridge, has been elected a Fellow of the Society.

\section{American Academy of Arts and Sciences : Foreign Honorary Members}

THE following have recently been elected foreign honorary members of the American Academy of Arts and Sciences: Henri Cartan, professor of mathematics, University of Paris; Sir John Cockeroft, director, Atomic Energy Research Establishment, Harwell ; P. A. M. Dirac, professor of mathematics, University of Cambridge; W. Pauli, professor of theoretical physics, Swiss Federal Institute of Technology, Zurich ; E. Schrödinger, senior professor, Dublin Institute for Advanced Studies; G. C. de Hevesy, associate professor, Institute of Research in Organic Chemistry, University of Stockholm ; Adolph Meyer, chief engineer, Brown Boveri and Co., Ltd., Baden; H. G. Lundegårdh, professor of plant physiology and director, Institute at Lantbrukshögskolan, Uppsala ; K. U. Linderström-Lang, director, Carlsberg Laboratory, Copenhagen; R. A. Peters, professor of biochemistry, University of Oxford; Hugo Theorell, of the Medical Nobel Institute, Stockholm; W. G. Penfield, professor of neurology and neurosurgery, McGill University.

\section{Unesco Science Co-operation Office for Latin America}

As an outcome of the Latin-American conference for the development of science, held in Montevideo in September 1948, the Unesco Science Co-operation Office for Latin America was opened in Montevideo a little more than a year ago. In his survey of the first year of its activities, the head of the Office, Dr. A. Establier, reports that the start was very successful. Requests for scientific liaison have been steadily increasing. The Office has been asked to assist in many hundreds of problems and has supplied bibliographies, scientific literature, type cultures, etc., and, generally, information on subjects touching on every branch of seience. Among the publications of the Office may be mentioned "List of Scientists and Scientific Institutions in Latin America", four volumes of which have now been published, and "List of Latin. American Scientific Papers published during 1948" (see Nature, April 15, p. 589). The Office has initiated the creation of a centre for the study of cosmic radiation and high-altitude physics at Morococha, Peru $(4,500 \mathrm{~m}$. above sea-level), which should become an important centre for such research, not only for Latin America, but of interest also for scientific workers from other parts of the world. It has also sponsored the first Latin-American conference on marine biology in Valparaiso, Chile, has collaborated with the Government of Peru in organising the symposium on high-altitude biology, recently held in Lima, and has stimulated the formation of new scientific societies. Through the Office, Latin-American men of science have also given valuable help to other countries ; for example, when the maize-fields of the Philippines were ravaged by insect pests, seeds of more resistant varieties of maize were forwarded, and these are now being successfully grown there on an experimental basis. Plans have been worked out for 